\title{
Effect of Androgen and Schistosomicide In Murine Schistomiasis Mansoni: An Experimental Study
}

\author{
Nabil Abdel Mageed (M.D.)*; Ehsan Hassan (M.D.) **, Nagwa M. Abdel Wahab \\ (Ph.D.) *** and Azza Hegazy (M.D.) **
}

\author{
Dermatology Department *, Pathology Department**, Biostatistics and \\ Public Health Department $* * *$. \\ National Hepatology and Tropical Medicine Research Institute (NHTMRI)
}

\begin{abstract}
Background: Impotence is a consistent inability to sustain an erection sufficient for sexual intercourse. Testosterone administration in men with liver cirrhosis improves the sense of well-being, increase serum proteins and reduces edema without serious adverse effects. Oral, alkylated forms of testosterone can create a situation of liver toxicity. There is little evidence that other methods of administration cause liver dysfunction. Most doctors be indecisive on prescribing androgen preparations in patients with liver disease, so this work was designed to study the effect of androgen replacement (injectable form) on the murine diseased liver, and subsequently whether it can be used safely in men with chronic liver disease or not.

Objective: To evaluate the effect of exogenous injectable androgen and praziquantel on the diseased liver of mice.

Setting: National Hepatology and Tropical Medicine Research Institute (NHTMRI).

Materials and methods: Forty male mouse (weighing 25-30 g) were infested subcutaneously with Schistosoma mansoni (100 cercariae/animal), and then they were divided into four groups. Mice in the first group were infected only and used as infected control group. Mice of group II and IV were given the Schistosomicide, praziquantel in a dose of $0.3 \mathrm{mg} / \mathrm{mouse}$. Androgen (Sustanon) was injected intramuscularly in a dose of $0.125 \mathrm{mg} / \mathrm{mouse}$, (three doses, 3 weeks apart) in group III and IV. At the end of the trial all animals were then sacrificed to study histopathologically the possible effects of androgen on the liver tissue. Liver function tests were done in animals of group I, III, and IV, first prior to study and finally by the end of study. Results of assayed liver function tests and histopathological examination were tested for statistical significant association.

Results: there were marked elevation of the liver enzymes in mice of group IV compared to the corresponding control $(\mathrm{p}<0.01)$ and mice of the third group $(\mathrm{p}<0.01)$, which reflect deterioration of hepatic function in those mice received the antibilharzial drug praziquantel. On the other hand there was statistical difference between control group (group I) and androgen treated group III $(\mathrm{P}<0.05)$. Histological examination of liver sections of mice in all groups revealed the presence of typical bilharzial granulomas. The mean diameter of bilharzial granulomas clearly dropped to 283.20 micrometer in group II compared to 392.55 in corresponding control. The difference between these two groups was statistically significant $(\mathrm{p}$ $=0.000)$. ). In group III there was no statistical difference in the number of egg granulomas $(\mathrm{P}\rangle$ $0.05)$ compared to group I. There was a reduction of granulomas diameter in group III and IV (animals injected with androgen) in comparison to group I $(\mathrm{P}>0.05$ and $\mathrm{P}<0.01)$ respectively. Also comparison between the four groups as regards the type of bilharzial granulomas, it is clearly evident that the predominant type of granulomas in the androgen treated groups is the cellular type (38\% and 57.1\%) in group III and IV respectively and this may reflect the possible beneficial effect of androgen on the diseased liver.
\end{abstract}


Conclusion: Our results clearly indicate that androgen have no deleterious effects on tissues of the diseased liver and hence on liver functions. In conclusion androgen therapy (injectabl form) appears to be safe in the clinical management of erectile dysfunction in patients with chronic liver disease.

\section{Introduction}

The liver does so much for our body, as we all know, but what many people do not know is that the liver is absolutely essential to our sex lives. The liver provides enzymes that produce the neurotransmitters Acetylcholine, Nitric Oxide (NO), and the erectile dilator cyclic Guanylate Monophosphate (cGMP). If the liver produces too much Phosphodiesterase (PDE) type 5, which blocks the action of cGMP on the penile erectile tissues, then a man might have trouble with his erection. In addition, the liver produces another enzyme called Aromatase that converts testosterone to estradiol and androstenedione to estrone. Too much Aromatase will lower the level of testosterone and reduce libido. 5-alpha reductase is another enzyme produced by the liver to convert testosterone into Dihydrotestosterone (DHT). DHT is used to recharge the bioelectricity of the nervous functions during sexual activities. However, too much DHT can lead to unwanted consequences. DHT has been linked to hair loss, prostate inflammation, and acne. The production of too much DHT will trigger those effects (McNiff, 2004). Impotence involves the inability to achieve and maintain penile erection sufficient to complete satisfactory intercourse (Steidle, 2003). Gynecomastia, testicular atrophy and impotence may be seen in chronic liver disease. Their pathogenesis is still poorly understood, but altered metabolism of sex hormones by the diseased liver appears important. The abnormalities may be seen in any chronic hepatic disorder, but are especially prevalent in alcoholic liver disease; this probably relates in part to a direct toxic effect of ethanol on gonadal function. (Steidle, 2003 and Simon, 2004). Androgen replacement therapy can improve the lives of men who are clinically hypogonadal; by restoring them to a eugonadal state, as in the case of chronic liver disease. Androgen preparations consist of oral, parenteral, transdermal patches, and topical gels. It is strongly recommended against using the oral medications; because of hepatotoxicity as well as because of low drug levels from first-pass inactivation through the liver. Kley et al, 1979, Gluud et al, 1981 and Puliyel et al, 1977 mentioned that testosterone administration in men with liver cirrhosis improve the sense of well-being, increase serum proteins and reduces edema without serious adverse effects. Most doctors be indecisive on prescribing androgen preparations in patients with liver disease, so this work was designed to study the effect of androgen replacement on the murine diseased liver, and subsequently whether it can be used safely in men with chronic liver disease or not.

\section{Materials and methods}

The study was conducted from March to May 2004.

Animals. This study was performed on forty sexually mature Swiss male albino mice. They were about $6-7$ weeks old, average weight 20 - 25 grams. Animals were allowed to stabilize for a minimum of 6 days within our facility before treatment. Food and water were allowed ad libitum and they were housed at room temperature. The animals were randomly divided into four groups, each comprised 10 mice. All groups were infected by subcutaneous injection of 100 Schistosoma Mansoni cercariae per mouse according to Peters and Warren, (1969):

1-First group $($ no $=10)$ were infected only with bilharziasis, and used as infested control group.

2-Second group $($ no $=10)$ were infected with bilharziasis and received antibilharzial treatment 
3-Third group (no = 10): which were infected with bilharziasis, then injected with androgen.

4-Fourth group (no $=10$ ) which were infected with bilharziasis, then injected with androgen. and received antibilharzial treatment.

Mode of infestation: Subcutaneous, with Schistosoma mansoni (100 cercariae/ mouse). The cercariae were kindly offered from Theodor Bilharz Research Institute.

Androgens: Each mouse in the third and fourth groups was injected intramuscularly with Sustanon, in a dose of 0.125 $\mathrm{mg} / \mathrm{mouse}$, for 3 injections, 3 weeks apart.

Liver function tests: Serum levels of GOT/AST, GPT/ALT, and ALK. Phosphatase were estimated in all animals, first prior to study and finally by the end of study. Blood samples were drawn via an indwelling cannula in the tail artery.

Antibilharzial treatment: Praziquantel was given in a dose of $0.3 \mathrm{mg} / \mathrm{mouse}$, orally tubal administered after being dissolved in distilled water for mice in group II and IV.

Light microscopic study: At the end of the trial all animals were sacrificed to study the possible effects of androgen on the liver tissue. The liver biopsies were removed, fixed in $10 \%$ buffered formaline solution then they were dehydrated in ascending grades of ethyl alcohol, 50, 70, 90\% and absolute alcohol. The materials were cleared in xylol, and then they were embedded in paraffin wax and prepared for sectioning. Sections were cut at a thickness of about $5 \mu$. The sections were mounted on slides and stained with Hematoxylin and Eosin as well as Masson-trichrome stains for assessment of fibrosis.

Measurement of bilharzial granulomas: Diameters were performed in different five fields for each mouse. The mean diameter of each granuloma was calculated by measuring two diameters of the lesion at right angles to each other, by using standardized linear ocular micrometer according to Von Lichtenberg et al, 1962.

Statistical analysis: Results of assayed liver function tests and histopathological examination were complied, tabulated and statistically analyzed using SPSS program release 11.01 which used for data management and calculation of mean, standard deviations and standard errors to describe quantitative data and compare proportions.

Comparisons were done between each two groups of the four groups as regards bilharzial granulomas diameter and number by using one tailed independent student $\mathrm{t}$ test. For comparisons between group I, II and III concerning the mean values of the liver function tests, Mann- Whitney test, a non-parametric test equivalent to the student t-test, was used. Categorical or qualitative data as type of the granulomas were presented using descriptive statistics in the form of frequencies, percentages and cross tabulation. These data were compared using Pearson Chi - square test, to test proportion independence. Statistical significance was considered at $\mathrm{P}$ - value < 0.05 (Bryman and Cramer, 1999).

\section{Results}

The mortality rate of mice in group II and IV was $20 \%$ and $10 \%$ respectively, while in infected control group was $20 \%$.

\section{Liver function tests (Table 4 \&5)}

It was noticed that there were marked elevation of the liver enzymes, in mice of group IV compared to the corresponding control (group I) and mice of the third group. This rise in liver enzymes reflects deterioration of hepatic function in those mice received the antibilharzial drug praziquantel and androgen.

Light microscopic results (Table1, 2, $3 \&$ Fig1, 2, 3 \&4)

Histological examination of liver sections of mice in all groups revealed the presence of typical bilharzial granulomas, which consists of central ova surrounded by lymphocytes, oesinophils, foreign body 
giant cells and fibroblasts (Fig. 1 \&4). Liver sections of group I (infected control group) revealed the presence of large number of fibrous granulomas and varying degrees of hydropic degeneration of hepatocytes. Livers of group II (praziquantel treated) revealed less number of fibrocellular and fibrous granulomas with predominance of cellular granulomas. In the androgen treated group (group III) there was no statistical difference in the number of egg granulomas $(\mathrm{P}=0.16)$ compared to the infected control group, however the mean diameter was slightly decreased but with no statistical significant difference $(\mathrm{P}=0.27)$ with increased number of cellular granulomas (38\%) (Fig. 3 Table 1, 2\&3). The granulomas diameter was variable from group to group. The mean granulomas diameter in mice of group 4 was 329.20 microns, in the control group (group 1) 392.55 microns, in group two 283.20 microns and in the third group it was 380.70 microns. The mean diameter of the granulomas diameter clearly dropped to 283.2 in the second group (infested with bilharziasis and received antibilharzial treatment) compared to 392.55 in corresponding control (Table 1, 2). The difference between these two groups was highly statistically significant $(\mathrm{P}=0.000)$ and this drop in granulomas diameter may reflect the effectiveness of the antibilharzial treatment. There was a reduction of the granulomas diameter in androgen treated groups (III\&IV) in comparison to corresponding control $(\mathrm{P}=0.27$ and $\mathrm{P}=0.0001)$ respectively. Tables (4) and (5) show means, standard deviations and standard errors values and comparison of liver function tests in the three-studied group. Table (5) shows that there is highly statistical difference between group (I) and (III) as regards AST and ALT test $(\mathrm{P}<$ 0.000 ) except for alkaline phosphatase test which shows significant difference $(\mathrm{P}=$ 0.012). Table (5) shows the comparison between group (I) and (IV) as regards the liver function tests, there is highly significant difference between the study groups.

Table (1): Values of bilharzial granulomas diameter and number of bilharzial granulomas among the four groups. (SD = Standard Deviation SE = Standard Error).

\begin{tabular}{|l|l|l|l|l|l|l|}
\hline Groups & \multicolumn{3}{|l|}{ Bilharzial granulomas diameter } & \multicolumn{2}{l|}{ Number of bilharzial granulomas } \\
\cline { 2 - 7 } & $\begin{array}{l}\text { No. Of Of } \\
\text { microscopic } \\
\text { fields }\end{array}$ & Mean \pm SD & $\begin{array}{l}\text { No. } \\
\text { microscopic } \\
\text { fields }\end{array}$ & Mean \pm SD & SE \\
\hline Group 1 & 40 & $392.55 \pm 102.56$ & 16.22 & 40 & $4.03 \pm 1.37$ & 0.22 \\
\hline Group 2 & 40 & $283.2 \pm 50.08$ & 7.92 & 40 & $3.73 \pm 1.3$ & 0.206 \\
\hline Group 3 & 50 & $380.07 \pm 81.7$ & 11.55 & 50 & $4.4 \pm 1.8$ & 0.26 \\
\hline Group 4 & 45 & $329.2 \pm 74.4$ & 11.10 & 45 & $6.36 \pm 1.96$ & 0.29 \\
\hline
\end{tabular}


Table (2): Comparison between the four groups concerning mean values of diameter and number of bilharzial granulomas by independent samples test.

\begin{tabular}{|l|l|l|l|l|}
\hline \multirow{2}{*}{ Groups } & \multicolumn{2}{|l|}{ Bilharzial granulomas diameter } & \multicolumn{2}{l|}{ Number of bilharzial granulomas } \\
\cline { 2 - 5 } & t- test value & P value & t- test value & P value \\
\hline $\begin{array}{l}\text { Group 1 versus } \\
\text { group 2 }\end{array}$ & 6.059 & $0.000^{* *}$ & 1.005 & 0.159 \\
\hline $\begin{array}{l}\text { Group 1 versus } \\
\text { group 3 }\end{array}$ & 0.612 & 0.271 & -0.994 & 0.162 \\
\hline $\begin{array}{l}\text { Group 1 versus } \\
\text { group 4 }\end{array}$ & 3.282 & $0.001^{* *}$ & -0.662 & $0.000^{* *}$ \\
\hline $\begin{array}{l}\text { Group 2 versus } \\
\text { group 3 }\end{array}$ & -6.96 & $0.000^{* *}$ & -1.92 & $0.029^{*}$ \\
\hline $\begin{array}{l}\text { Group 2 versus } \\
\text { group 4 }\end{array}$ & -3.38 & $0.0005^{* *}$ & -7.37 & $0.000^{* *}$ \\
\hline $\begin{array}{l}\text { Group 3 versus } \\
\text { group 4 }\end{array}$ & 3.194 & $0.001^{*}$ & -5.14 & $0.000^{* *}$ \\
\hline
\end{tabular}

*: Significant at $\mathrm{p}<0.05$

**: Highly significant at $\mathrm{p}<0.01$

Table (3) Comparison between the four groups as regards their type of granulomas.

\begin{tabular}{|l|l|l|l|l|l|l|}
\hline $\begin{array}{l}\text { Type } \\
\text { Granulomas }\end{array}$ & Group (1) & Group (2) & $\begin{array}{l}\text { Group } \\
(3)\end{array}$ & Group (4) & $\begin{array}{l}\text { Chi-square } \\
\text { value }\end{array}$ & P value \\
\hline Fibrous & $\begin{array}{l}48 \\
(58.5 \%)\end{array}$ & $\begin{array}{l}25 \\
(33.8 \%)\end{array}$ & $38(32 \%)$ & $86(42.4 \%)$ & & \\
\hline Cellular & $\begin{array}{l}18 \\
(22 \%)\end{array}$ & $\begin{array}{l}28 \\
(37.8 \%)\end{array}$ & $45(38 \%)$ & $\begin{array}{l}116 \\
(57.1 \%)\end{array}$ & 82.35 & \\
\cline { 1 - 5 } & $\begin{array}{l}21 \\
(28.4 \%)\end{array}$ & $35(30 \%)$ & $\begin{array}{l}1 \\
(0.5 \%)\end{array}$ & & \\
& Fibro-cellular & $(19.5 \%)$ & & & \\
\end{tabular}

**: Highly significant at $\mathrm{p}<0.01$

Table (4): Values of AST, ALT and Alkaline phosphatase tests among the three different groups.

\begin{tabular}{|c|c|c|c|c|c|c|c|c|c|}
\hline \multirow[b]{2}{*}{ Groups } & \multicolumn{3}{|c|}{ AST (U/L) } & \multicolumn{3}{|c|}{$\operatorname{ALT}(\mathrm{U} / \mathrm{L})$} & \multicolumn{3}{|c|}{ Alkaline phosphatase (U/L) } \\
\hline & $\begin{array}{l}\text { No. of } \\
\text { mice }\end{array}$ & Mean \pm SD & SE & $\begin{array}{l}\text { No. of } \\
\text { mice }\end{array}$ & Mean \pm SD & SE & $\begin{array}{l}\text { No. of } \\
\text { mice }\end{array}$ & $\begin{array}{ll}\text { Mean } & \pm \\
\text { SD } & \\
\end{array}$ & SE \\
\hline $\begin{array}{l}\text { Group } \\
\text { (1) }\end{array}$ & 8 & $98 \pm 4.345$ & 1.54 & 8 & $38 \pm 3.3$ & 1.17 & 8 & $87 \pm 2.8$ & 0.99 \\
\hline $\begin{array}{l}\text { Group } \\
\text { (3) }\end{array}$ & 10 & $992 \pm 54.45$ & 17.22 & 10 & $172.1 \pm 18.99$ & 4.8 & 10 & $89 \pm 5.9$ & 1.88 \\
\hline $\begin{array}{l}\text { Group } \\
\text { (4) }\end{array}$ & 9 & $1323 \pm 43.33$ & 14.4 & 9 & $220 \pm 42.9$ & 14.3 & 9 & $132 \pm 21.7$ & 7.2 \\
\hline
\end{tabular}


Table (5): comparison of liver function tests in the three studied groups by Mann-Whitney test

\begin{tabular}{|ll|l|l|l|l|l|l|}
\hline \multirow{2}{*}{ Groups } & \multicolumn{2}{|l|}{ AST (U/L) } & \multicolumn{2}{l|}{ ALT (U/L) } & \multicolumn{2}{l|}{$\begin{array}{l}\text { Alkaline } \\
\text { (U/L) }\end{array}$} \\
\cline { 3 - 8 } & $\begin{array}{l}\text { Z } \\
\text { test }\end{array}$ & P value & $\begin{array}{l}\text { Z } \\
\text { test }\end{array}$ & P value & Z test & P value \\
\hline $\begin{array}{l}\text { Group (1) versus group } \\
\text { (3) }\end{array}$ & -3.79 & $0.000^{* *}$ & -3.79 & $0.000^{* *}$ & -2.3 & $0.012^{*}$ \\
\hline $\begin{array}{l}\text { Group (1) versus group } \\
\text { (4) }\end{array}$ & -3.7 & $0.000^{* *}$ & -3.67 & $0.000^{* *}$ & -3.6 & $0.000^{* *}$ \\
\hline $\begin{array}{l}\text { Group (3) versus group } \\
\text { (4) }\end{array}$ & -3.9 & $0.000^{* *}$ & -3.14 & $0.001^{* *}$ & -3.14 & $0.001^{* *}$ \\
\hline
\end{tabular}

*: Significant at $\mathrm{p}<0.05$

**: Highly significant at $\mathrm{p}<0.01$

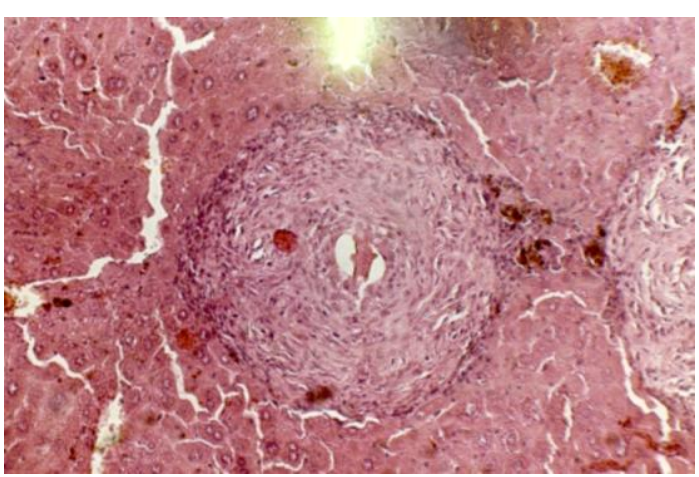

Fig. 1: infected control group showing typical bilharzial granuloma with viable egg (H\&E, X150)

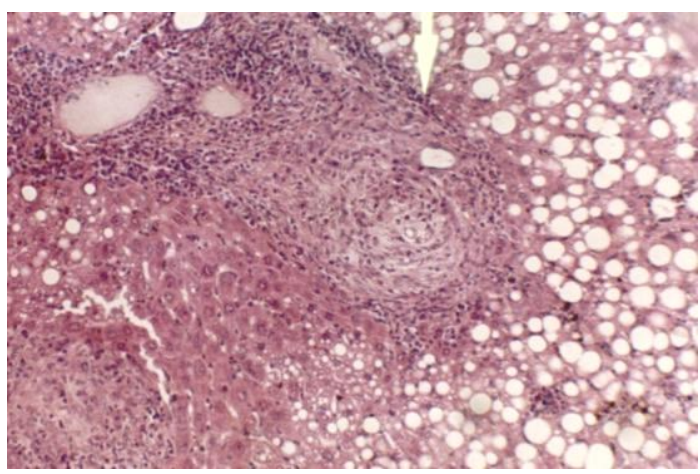

Fig. 3: androgen treated group with cellular granulomas and fatty degeneration of hepatocytes (H \& E, X150)

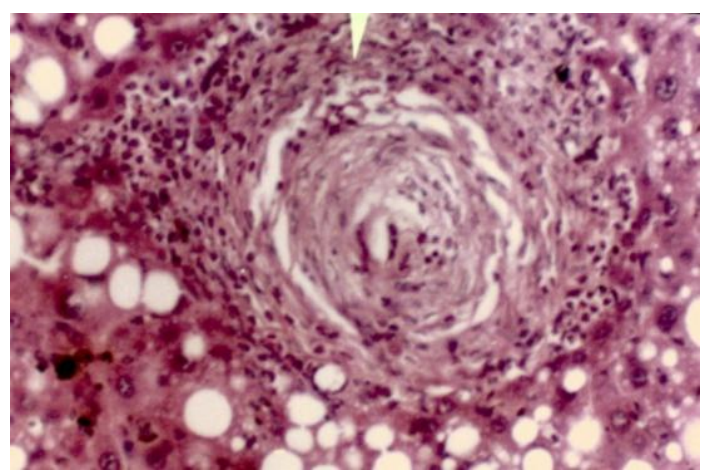

Fig. 2: praziquantel and androgen treated group showing fibro-cellular granuloma and fatty degeneration of hepatocytes (H\&E, X150)

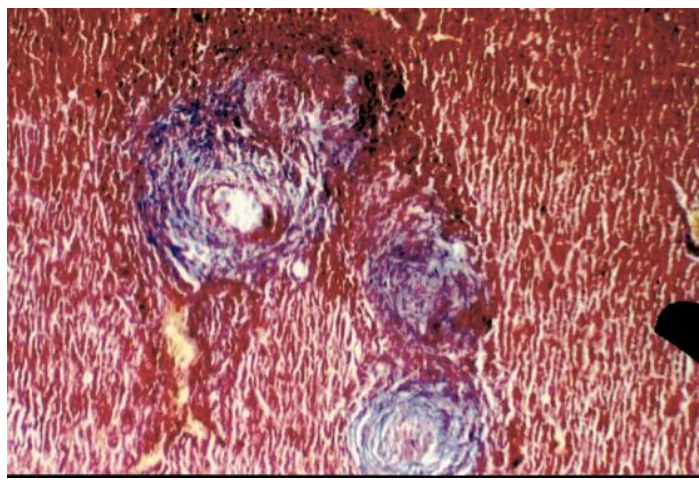

Fig. 4: infected control group showing multiple bilharzial granulomas (Masson trichrome stain, X 150) 


\section{Discussion}

Impotence is a consistent inability to sustain an erection sufficient for sexual intercourse. Medical professionals often use the term "erectile" dysfunction" to describe this disorder and to differentiate it from other problems that interfere with sexual intercourse, such as lack of sexual desire and problems with ejaculation and orgasm. Impotence usually has a physical cause, such as disease, injury, or drug side effects. Any disorder that impairs blood flow in the penis has the potential to cause impotence. Incidence rises with age: about 15 percent of men at the age of 40 and between 45 and 50 percent of men at the age of 65experience impotence. In men who are identified as having a low testosterone (total and or bioavailable) and have difficulties with erectile function, testosterone therapy may be tried prior to moving on to more invasive tests or therapies. In the event that normal sexual function returns with replacement, then further evaluation is unnecessary, many elderly men with impotence will have multiple factors leading to their impotence problem and simple hormonal replacement will not result in return of normal sexual activity in most. When a trial of testosterone is unable to return a man to normal sexual function, but there are beneficial effects on libido, the wisdom of proceeding on with ongoing androgen therapy is less well established. Oral, alkylated forms of testosterone can create a situation of liver toxicity. There is little evidence that other methods of administration cause liver dysfunction (Daniel, 2003 and Ohl, 2003). Approximately $50 \%$ of cases of ED are caused by physical, not psychological problems. Hypertension, low testosterone serum level (such as patients receiving hormonal therapy for prostate cancer or patients with hypogonadotropic hypogonadism), hyperprolactinemia, diabetes, coronary artery disease, peripheral vascular disease, anemia, medications, smoking, alcohol abuse, surgical procedures vascular surgeries, abdomino-perineal resection, radical prostatectomy and psychiatric illness such as anxiety disorder, depression and obsessive-compulsive disorder. In addition to the conditions mentioned before, other causes of ED include the following: Penile implant or prosthesis that is not functioning properly, stress, recreational drugs such as cocaine, marijuana, alcohol, or heroin, liver disease, usually caused by alcoholism. Gynecomastia, testicular atrophy and impotence may be seen in chronic liver disease. Their pathogenesis is still poorly understood, but altered metabolism of sex hormones by the diseased liver appears important. The abnormalities may be seen in any chronic hepatic disorder, but are especially prevalent in alcoholic liver disease; this probably relates in part to a direct toxic effect of ethanol on gonadal function (Steidle, 2003 and Simon, 2004). Androgen replacement therapy can improve the lives of men who are clinically hypogonadal; by restoring them to a eugonadal state, it can increase muscle mass and strength, help maintain bone density, increase cognition and mood, improve libido and sexual function, and lead to a generalized state of well-being. Androgen preparations consist of oral, parenteral, transdermal patches, and topical gels. It is strongly recommended against using the oral medications; because of hepatotoxicity as well as because of low drug levels from first-pass inactivation through the liver. A form of testosterone lacking the methyl group that leads to hepatotoxicity is available in Europe but not in the United States (testosterone undecanoate). Injectable preparations cause wide swings in testosterone levels, and sometimes patients cannot tolerate the accompanying mood changes. Side effects of exogenous androgen therapies are mood changes, polycythemia, gynecomastia, exacerbation of sleep apnea, and in some patients, acne. Most symptomatic hypogonadal men can find a tolerable medication and will benefit from it (Daniel, 2003). Sustanon is a very popular steroid, which is highly appreciated by its users since it offers several advantages when 
compared to other testosterone compounds. Sustanon is a mixture of four different testosterones, which, based on the welltimed composition, have a synergetic effect (Testosterone propionate $30 \mathrm{mg}$, Testosterone phenylpropionate 60mg, Testosterone isocaporate $60 \mathrm{mg}$, Testosterone decanoate $100 \mathrm{mg}$ ). This special feature has two positive characteristics, first, based on the special combination effect of the compounds, Sustanon, has a better effect than Testosterone enanthate, cypionate, and propionate alone. Second, the effect of the four testosterones is time-released so that Sustanon goes rapidly into the system and remains effective in the body for $2-3$ weeks. Due to the propionate included in the steroid, Sustanon is effective after one day and, based on the mixed in decanoates, remains active for 3-4 weeks. Sustanon has a distinct androgenic effect, which is coupled with a strong anabolic effect (Parma Europe.com, 2004). Liver is the major site of ethanol clearance and its subsequent metabolism. Ethanol is oxidized principally by two major pathways primarily involving alcohol dehydrogenase (ADH) and CYP2E1. These enzymes are located in the cytosol and endoplasmic reticulum, respectively, and oxidize ethanol to acetaldehyde, which is rapidly metabolized to acetate by aldehyde dehydrogenase (Lieber, 1997). Some authors have shown that estrogen increased and testosterone decreased hepatic ADH activities, whereas others have found no effect (Mezey et al, 1981). Androgens downregulated $\mathrm{ADH}$-specific activity in some studies, but not others, whereas estrogens increased hepatic ADH-specific activity in male rats but not females (Crabb et al, 1986). Prolonged use of high doses of orally active 17-alpha-alkyl androgens (e.g., methyl testosterone) has been associated with the development of peliosis hepatic, cholestatic jaundice and hepatic neoplasms, including hepatocellular carcinoma. Peliosis and hepatic affection can be a lifethreatening or fatal complication. Pure testosterone is not known to produce these adverse effects. (The American Liver Foundation. 2002-2003). In our study it was noticed that there were marked elevation of the liver enzymes in mice of group four compared to the corresponding control (group I) and mice of the third group, which reflect deterioration of hepatic function in those mice received the antibilharzial drug praziquantel. At the same time the mean diameter of the bilharzial granulomas clearly dropped to 283.20 micron in the second group (infested with bilharziasis and received antibilharzial treatment) compared to 392.55 micron in corresponding control (Table 1,2). The difference between these 2 groups was statistically significant and this drop in granulomas diameter may reflect the effectiveness of the antibilharzial treatment. Decreased diameter of granulomas size was evident in animals injected with androgen (group III) compared to those animals in group one and two, but statistically insignificant. Also comparison between the four groups as regards their type of the granulomas, it is clearly evident that the predominant type of granulomas in the androgen treated groups is the cellular type and this may reflect the possible beneficial effect of androgen on the diseased liver. In agreement with this, Kley et al, 1979, Gluud et al, 1981 and Puliyel et al, 1977 mentioned that testosterone administration in men with liver cirrhosis improve the sense of well-being, increase serum proteins and reduces edema without serious adverse effects. In schistomiasis, pathophysiology is associa-ted with granulomatous hypersensitivity reaction around the eggs in host tissue (Perrin and Phillips, 1989). Although the role of this reaction is to stop diffusion of schistomiase egg toxic products and histolytic secretions which causes damage and necrosis to the surrounding liver tissue (Rashed et al, 1997), the chronic granulomatous inflammation and reparative fibrosis in the liver are the major causative factors in the pathogenesis of the disease (Yamashita and Boros, 1992). On the other hand Nayera et $a l$, (1999) in their experimental work on murine schistomiasis mansoni documented that cortisone reduced number of liver and intestinal egg load, number of adult worms and granulomas size. This was in agreement with our results, as we noticed reduction in 
the granulomas size, with increased number of cellular granulomas in mice injected with the male sex steroids (androgen). Matthias et al, (1997) also mentioned that male sex steroids are responsible for depressing macrophage immune function after traumahemorrhage Our results clearly indicate that androgen have no deleterious effects on tissues of the diseased liver and hence on liver functions.

\section{Conclusion}

Our results clearly indicate that androgen have no deleterious effects on tissues of the diseased liver and hence on liver functions. In conclusion androgen therapy (injectable form) appears to be safe in the clinical management of erectile dysfunction in patients with chronic liver disease. Aggressive research directed at understanding the pathogenesis of erectile dysfunction in patients with chronic liver disease is the most promising approach to the development of effective treatments.

\section{Summary}

Oral, alkylated forms of testosterone can create a situation of liver toxicity. There is little evidence that other methods of administration cause liver dysfunction. Kley et al, 1979, Gluud et al, 1981 and Puliyel et al, 1977 mentioned that testosterone administration in men with liver cirrhosis improve the sense of well-being, increase serum proteins and reduces edema without serious adverse effects. Forty male albino mice (weighing 25-30 g) were infested subcutaneously, with Schistosoma Mansoni (100 cercariae/animal), then they were divided into four groups. Mice in the first group did not receive any medication. In the second group, animals received the antibilharzial treatment (praziquantel). In the third group each mouse underwent 3 injections intramuscularly with Sustanon, 3 weeks apart. Animals in the fourth group were infested with bilharziasis, injected with androgen and received antibilharzial treatment. At the end of the trial all animals were then sacrificed to study histopathologically the possible effects of androgen on the liver tissue. Liver function tests were done in animals of the $1^{\text {st }}, 3^{\text {rd }}$, and $4^{\text {th }}$ group, first prior to study and finally by the end of study. Results of assayed liver function tests and histopathological examination were tested for statistical significant association. There were marked elevation of the liver enzymes in mice of group four compared to the corresponding control and mice of the third group, which reflect deterioration of hepatic function in those mice received the antibilharzial drug praziquantel. Histological examination of liver sections of mice in all groups revealed the presence of typical bilharzial granulomas. The mean diameter of bilharzial granulomas clearly dropped to 283.20 micrometer in group II compared to 392.55 in corresponding control The difference between these two groups was statistically significant $(p=0.000)$. ). In group III there was no statistical difference in the number of egg granulomas $(\mathrm{P}>0.05)$ compared to group I. There was a reduction of granulomas diameter in group III and IV (animals injected with androgen) in comparison to group I $(\mathrm{P}>0.05$ and $\mathrm{P}<0.01)$ respectively. Also comparison between the four groups as regards the type of bilharzial granulomas, it is clearly evident that the predominant type of granulomas in the androgen treated groups is the cellular type (38\% and $57.1 \%)$ in group III and IV respectively and this may reflect the possible beneficial effect of androgen on the diseased liver. Our results clearly indicate that androgen has no deleterious effects on tissues of the diseased liver and hence on liver functions. In conclusion androgen therapy (injectabl form) appears to be safe in the clinical management of erectile dysfunction in patients with chronic liver disease.

\section{References}

1-American Liver Foundation (2003): LiverFoundation .org

2- Bryman, A. and Cramer, D. (1999): Quantitative Data Analysis with SPSS for Windows; A Guide for Social Scientists, London Rout ledge. 
3-Crabb, D.W, Bosron W.F, and Li T.K. (1986): Role of the pituitary and neonatal androgenic imprinting in the hormonal regulation of liver alcohol dehydrogenase activity. Biochem Pharmacol 35: 1527-1532, 1986.

4-Daniel, K. (2003): ACP: Several Options Available for Androgen Replacement Therapy. webmaster@ docguide. Com. 2003.

5-Gluud, C., Bennett, P. and Dietrichsen, $O$. (1981): Short-term parenteral and peroral testosterone administration in men with alcoholic cirrhosis. Scand J Gastroenterol 16: $749-755$.

6-Kley, H.K., Strohmeyer, G. and Kruskemper, H.L. (1979): Effect of testosterone application on hormone concentrations of androgens and estrogens in male patients with cirrhosis of the liver. Gastroenterology $76: 235-241$.

7-Lieber, C. (1997): Cytochrome P-4502E1: its physiological and pathological role. Physiol Rev 77: 517-544, 1997.

8-Matthias, W., Wichmann, Alfred Ayala, and Chaudry, I. (1997):Am J Physiol Cell Physiol 273, (4): C1335-C1340.

9-McNiff, M. (2004): eviewed by HerboLove.com 2004.

10-Mezey, E, Potter J.J, and Tsitouras P.D. (1981): Liver alcohol dehydrogenase activity in the female rat: effects of ovariectomy and estradiol administration. Life Sci 29: 1117111174, 1981.

11-Nayera, R. Z., Amaj, A.E., Mona, M.M., Mona, M.K. and Salwa, H.M. (1999): Efficacy of cortisone as immumo-pharmacological therapy and schistomicide in murine schistomiasis mansoni.J. Egypt Soc. Path. 19: $457-465$.
12-Ohl, D. (2003): Low Androgens in Men Email: DrK @ wellnessmd. com13-Parma Europe. om (2004):

14-Perrin, P.J. and Phillips, S.M. (1989):The molecular basis of granulomas formation in schistomiasis. III in vivo effect of a $\mathrm{T}$ cell derived suppressor effector factor and IL-2 on granulomas formation.J. Immunol. 143: 649 654.

15-Peters, P.A. and Warrant, K.S. (1969):A rapid method of infecting mice and other laboratory animals with Schistosoma. Mansoni: subcutaneous injection.J. Parasitol. 131: 558 - 567.

16-Puliyel, M.M., Vyes, G.P. and Mehta, G.S. (1977):Testosterone in the management of cirrhosis of the liver - a controlled study.Aust NZ J Med 7: 17 - 30.

17-Rashed, A.A., Abou Senna, F.M., Sabry, A.H.A. and Morsy, T.A. (1997): Studies on granulomas formation in Syrian hamsters experimentally infected with Schistosoma. Mansoni.J. Egypt Soc. Path. 27: $411-418$.

18-Simon J.B. (2004): GITextbook/ en/ chapter14/ subheadings.htm

19-Steidle, C. (2003):Medical Reference from "The Impotence Sourcebook(C1996-2003 WebMD Inc.

20-Von Lichtenberg, F., Sudan, E.H. and Bruce, J.I. (1962): Tissue responses and mechanisms of resistance in Schistomiasis mansoni in an abnormal host. Am. J. Trop. Med. Hyg. 11: 347 - 356.

21-Yamashita, T. and Boros, D.L. (1992):IL-2 production and granulomatous inflammation in murine Schistomiasis mansoni. J. Immunol. 149: 3659 - 3664. 


\section{تأثير هرمون الاندروجين على كبد فئران التجارب المصابة

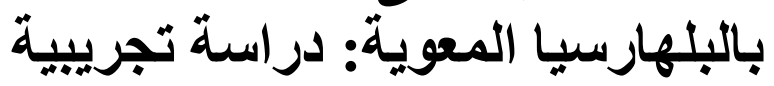

\section{نبيل عبد المجيد - إحسان حسن - نجوى عبد الوهابـ عزة حجازي المعهد القومى للأمر اض المتوطنة و والكبد الكهاب}

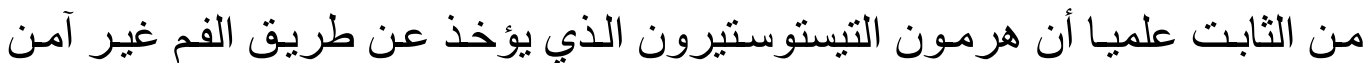

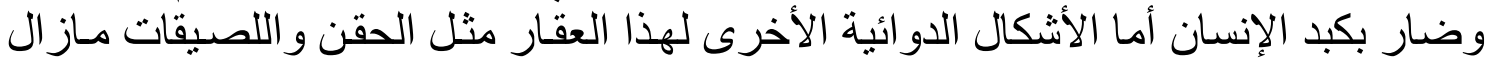

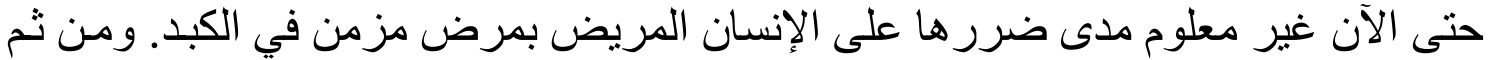
فقد تم تخطيط هذا البحث لإلقاء الضوء على على الآثار الضارة المحتملة لهذا العقار على الصى نسيج

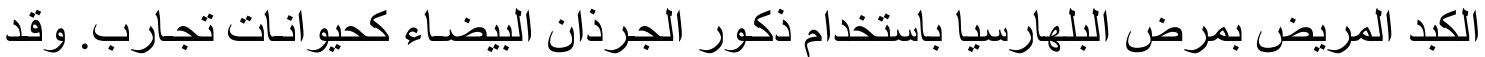
تمت عدوى الجرذان المستخدمة في هذه التجربة بو اسطة مذنبات بلهارسيا مانسونى 100$\}$

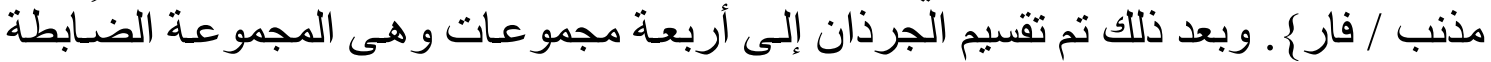

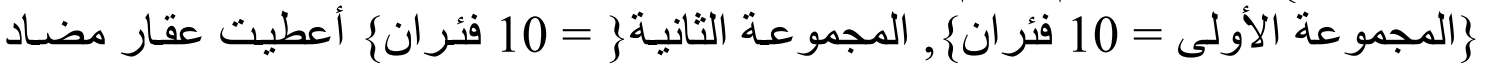

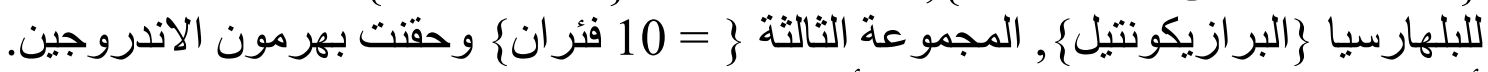
أما الجرذان في المجمو عة الر ابعة فقد أعطيت كلا من هرمون الاندروجين العين و البرازيكونتيل.

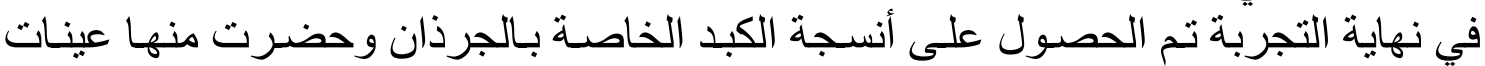

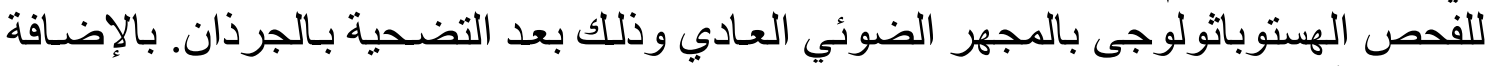

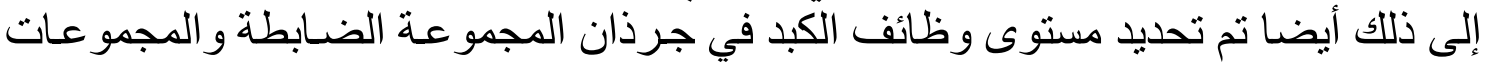

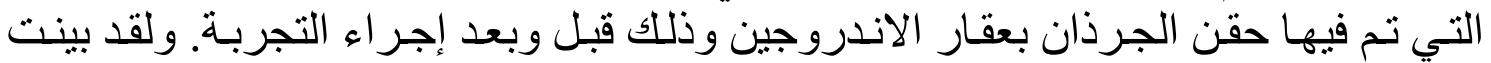

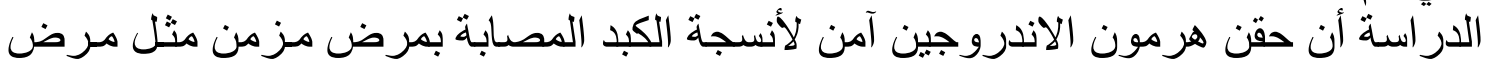

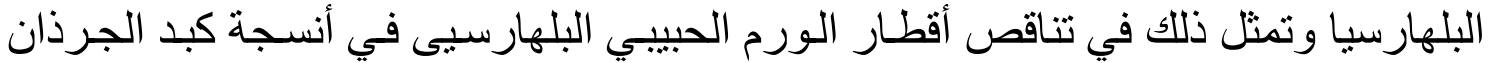

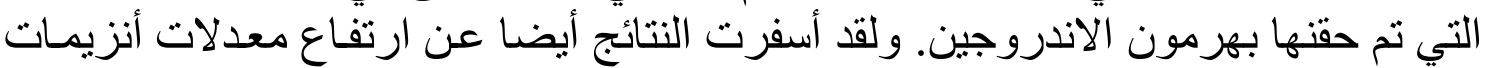

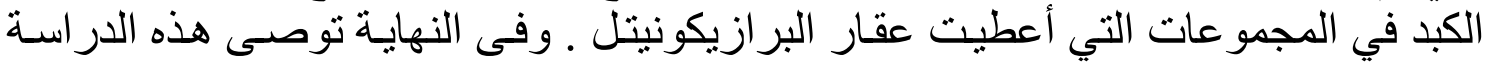

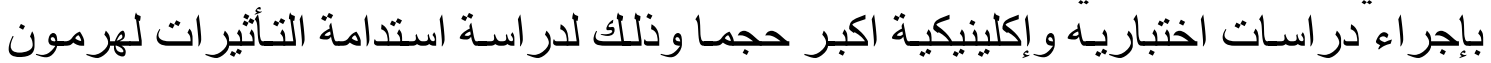

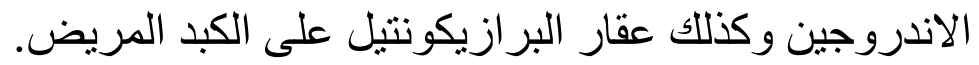

